
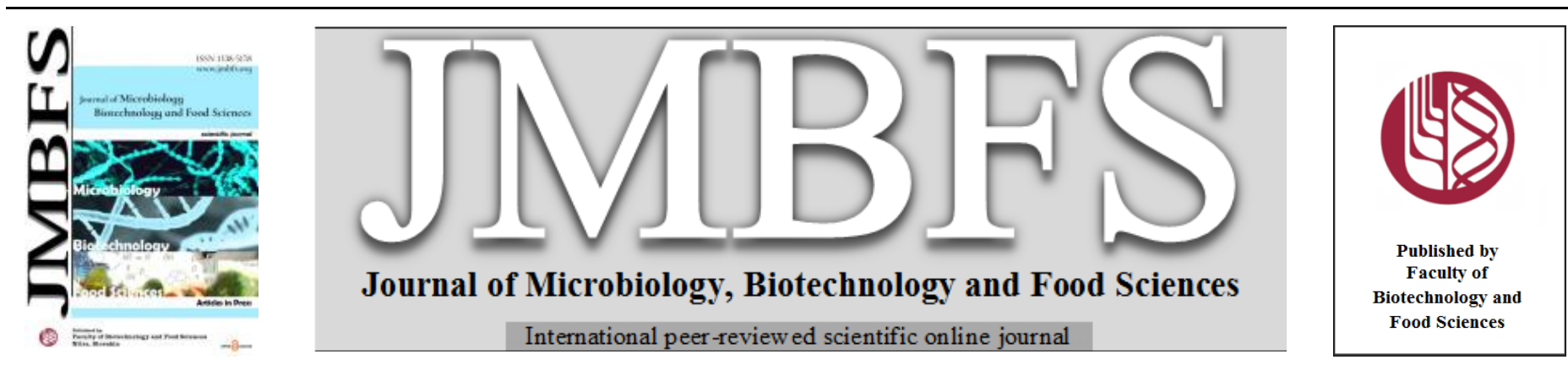

\title{
EVALUATION OF SOME TRADITIONAL THERAPEUTIC PROPERTIES OF USNEA LONGISSIMA (ASCOMYCOTA, LICHENIZED FUNGI): ANTIMICROBIAL, ANTIQUORUM AND ANTIOXIDANT
}

\author{
Shweta Bharti ${ }^{1,2}$, Sanjeeva Nayaka ${ }^{1}$, Rajesh Kumar*2 \\ Address(es): Prof. Rajesh Kumar \\ ${ }^{1}$ Lichenology Laboratory, CSIR-National Botanical Research Institute, Lucknow-226001, Uttar Pradesh, India. \\ ${ }^{2}$ Department of Microbiology, Babasaheb Bhimrao Ambedkar Central University, Lucknow-226025, Uttar Pradesh, India.
}

*Corresponding author: rajesh4971@yahoo.com

https://doi.org/10.55251/jmbfs.3163

\section{ARTICLE INFO}

Received 22. 5. 2021

Revised 13.9. 2021

Accepted 21.9. 2021

Published 1. 2. 2022

Regular article OPEN $\partial_{\text {ACCESS }}$

\begin{abstract}
Usnea longissima, fruticose lichen growing in the temperate region, is well known traditional medicinal herb and a reservoir of some unique secondary metabolites. Traditionally it has been commonly used as an antimicrobial agent for the treatment of ailments like tuberculosis, ulcers and skin diseases, etc. In our study, we evaluate antimicrobial, antiquorum sensing (QS) and antioxidant activity of Usnea longissima secondary metabolites extracted in acetone, methanol, and 70\% hydroalcoholic solvents. Antimicrobial activity of extracts was evaluated against fungus (Aspergillus niger, Candida albicans) and six bacterial (Agrobacterium tumefaciens, Escherichia coli, Klebsiella pneumoniae, Pseudomonas aerogenosa, Staphylococcus aureus, Streptococcus mutans) strains. Whereas anti-QS activity was tested against biosensor strain Chromobacterium violaceum (CV) MCC 2290 and antibiofilm activity was checked in two gram-negative bacteria (P. aeruginosa and E. coli), two gram-positive bacteria (Bacillus cereus and Staphylococcus aureus) and fungus (Candida albicans). Results of experimental data indicated that methanolic extract exhibited maximum activity against A. tumefaciens $(24 \pm 0.2 \mathrm{~mm})$ and C. albicans $(30 \pm 0.3 \mathrm{~mm})$ with the minimum inhibitory concentration of $300 \mu \mathrm{g} / \mathrm{mL}$ and $200 \mu \mathrm{g} / \mathrm{mL}$ respectively. Interestingly, we also observed that all extracts effectively inhibited quorum sensing in C. violaceum and biofilm formation in Bacillus cereus, Escherichia coli, Pseudomonas aerogenosa, Staphylococcus aureus, at the concentration (100-300 $\mu \mathrm{g} / \mathrm{mL})$, for Candida albicans $(50-150 \mu \mathrm{g} / \mathrm{mL})$. Usnea longissima extract showed strong reducing power and hydroxyl radical activity and low DPPH scavenging activity. The present study suggested that $U$. longissima possesses potential antimicrobial and antiquorum sensing activity. These biological properties could be attributed to its significant antioxidant potential which validates its traditional use as an antimicrobial herbal source.
\end{abstract}

Keywords: Antibiofilm; Infectious disease; Yeast; Antioxidant

\section{INTRODUCTION}

Lichens represent the most successful symbiotic relationship between fungi $(90 \%)$ and algae $(10 \%)$, sometimes cyanobacteria, survive in extreme environmental conditions and geographically distributed from tropical to the polar region, covering almost $8 \%$ of the earth's surface

(Alahmadi, 2017). Lichens have a wide array of unique secondary metabolites such as fatty acid polysaccharides, terpene, flavonoid depsides, depsidones, dibenzofurans, depsones which confer protection against biological attack and physical stress (Ullah et al., 2003). Lichens are used in traditional medicines as well as incontemporary homeopathic, naturopathic medicines (Madamombe and Afolayan, 2003). The most common uses of lichens are; for treating wounds, ulcers, respiratory and gastrointestinal issues. In the last three decades, studies explored antimicrobial, antiviral, antiprotozoal, antipyretic, antitumor, antiproliferative, anti-inflammatory, analgesic, antioxidant, and photoprotective activities of different lichens from different regions of the world (Behera $\boldsymbol{e t} \boldsymbol{a l}$., 2013; Bao et al., 2012; Correche et al., 2004; Paliya et al., 2016; Nishanth et al., 2015). In India, though the folklore and ethnic use of lichen as medicine were known from ancient times, however more systematic validation of such species initiated recently. Some of the macrolichens, commonly occurring in India such as species of Heterodermia, Parmotrema, Sticta, Ramalina and Usnea exploited for their preliminary biological screening against humans and plants pathogen (Shahi et al., 2001; Shivanna and Garampalli, 2014). Among the different lichen texa, the species of fruticose lichen, Usnea has been found growing luxuriantly in the Indian Himalayan region at around 3000 to 3500 meters. The species having usnic acid is well explored for its medicinal potential throughout the world (Paliya et al., 2016).

Most easily recognizable fruticose lichen, Usnea longissima Ach. (Dolichousnea longissima(Ach.) Articus) is also known as an old man's beard, belongs to the family Parmeliaceae. It is pale-green or light yellowish color usually grows on the bark of the old trees. The world's longest lichen $U$. longissima is a common inhabitant Western of Ghats and the Indian Himalaya region. U. longissima shows diversity in metabolite production and thereby getting attention from researchers; who have isolated and explored their hidden unique metabolite activities in different areas; such metabolites are usnic acid, diffractaic acid, evernic acid, salazinic acid, fumarprotocetraric acid, ramalinolic acid, squamatic acid, orcinol, and atranorin (Ullah et al., 2003; Dandapat and Paul, 2019). Other anti-inflammatory phenolic compounds are glutinol, longissiminone (Choudhary and Jalil, 2005). Usnea longissima is natural antioxidant and used to cure bone fractures, the leg and loin injuries, as an expectorant, immune strengtheners (Atalay et al., 2011; Rauf et al., 2011), to treat surface infection, Tuberculosis lymphadenitis (Blumenthal et al., 2000). American natives use $U$. longissima as a natural skin drug (Sudarwanti et al., 2018); significantly inhibit bacterial neuraminidase, saprolegniasis (Ullah et al., 2003; Guo, 2017). Usnea increases lactation in breastfeeding women (Verma et al., 2008).

Quorum sensing (QS) in bacteria is a cell communication process in which intercellular biochemical signal releases when cell density reaches high concentration (Girard and Bloemberg, 2008; Sifri, 2008; Solano et al., 2014; Gokalsin and Sesal, 2016). These signals aid to modify the gene expression and cascade the release of different virulence factors, biofilm formation (Sifri 2008; Al Wrafy et al., 2017). Biofilm and QS both are interdependent mechanisms and develop a new antibiotic-resistant lifestyle in bacteria. Such types of pathogenic bacteria are very dangerous for the host, for example, Pseudomonas aeruginosa Candida (Sifri, 2008; Solano et al., 2014; Millot et al., 2017) cause severe infection in an immune-compromised patient due to biofilm formation that confers resistance to antibiotics and hosts immune responses (Guo, 2017; Flemming and Wuertz, 2019; Shah et al., 2019) and gives an open challenge to herbal medicine. Usnic acid, a major metabolite in $U$. longissima (first time isolated by Knop in 1844) (Yu X et al., 2016), plays an important role in inhibiting biofilm formation in S. aureus (isolated from Cystic fibrosis patient) 
(Nithyanand et al., 2015) and $P$. aeruginosa by interfering with DNA, RNA synthesis and signaling pathway (Maciag-Dorszynska et al., 2014). Since QS determines the intensity of microbial infection, therefore inhibition of QS could be a better way or therapeutic practice against microbial disease without exerting selective pressure on microbe (the main cause of drug-resistant in bacteria). In the present study, an attempt has been made to evaluate the antimicrobial, antioxidant activity and investigate antiquorum sensing activity of $U$. longissima extracts through biofilm inhibition against some pathogenic microorganisms and validate its traditional use as herbal medicine.

\section{MATERIAL AND METHODS}

\section{Media, Chemicals and Microorganisms used}

TLC silica gel $60 \mathrm{~F}_{254}$ aluminum-backed plate, Streptomycin and ketoconazole, nutrient culture media and muller Hilton agar (MHA), potato dextrose agar (PDA), potato dextrose broth (PDB), nutrient broth (NB), DPPH, ascorbic acid, sodium nitrite, Aluminium chloride, sodium hydroxide, potassium ferri-cyanide, ferric chloride, hydrogen peroxide, trichloroacetic acid (TCA), TBA (thiobarbituric acid), sodium dodecyl sulphate (SDS), n-butanol were obtained from the Hi-Media Laboratories, Mumbai, India. Microorganism strains used in this study - Agrobacterium tumefaciens, Aspergillus niger, Candida albicans, Escherichia coli, Klebsiella pneumoniae, Pseudomonas aeruginosa, Staphylococcus aureus, Streptococcus mutans, Bacillus cereus, Chromobacterium violaceum (MCC 2290) obtained from NBRI and BBAU, Lucknow, India

\section{Collection of Sample}

The lichen sample was collected from the Uttarkashi district of Uttarakhand, India. The samples were segregated and identified by studying their morphology, anatomy, and chemistry. Voucher samples of the lichens were utilized and deposited in the herbarium of CSIR-National Botanical Research Institute Lucknow, India.

\section{Preparation of lichen extract}

The lichen samples were washed in tap water, tween 80 detergent was used to remove dirt and unwanted materials and then samples were scattered on sterile filter paper and left at room temperature till dry. The dried lichen sample $(30.6$ gm) was frozen with liquid nitrogen and crushed. The crushed material was divided into three equal amounts and extracted in soxhlets using three different solvents acetone, methanol, $70 \%$ hydroalcohol. The evaporation of the solvent in the extract was carried out in a rota vapour machine at a definite temperature for particular solvents to avoid any metabolite degradation. The final dried crude extract was weighed (Acetone $330.7 \mathrm{mg}, 70 \%$ hydroalcohol $453 \mathrm{mg}$ and Methanol $280.4 \mathrm{mg}$ ) and stored in Eppendorf tubes at $4^{\circ} \mathrm{C}$ for further preparation of the stock solution.

\section{Thin-layer chromatography}

Thin-layer chromatography is a simple fast sensitive and inexpensive solid-liquid analytical technique. TLC has been used to identify lichen compounds and study the specific group of lichen (mycobiont) secondary metabolites (Bendz et al. 1967; Molnar and Farkas, 2010). The fraction of $U$. longissima was immersed in acetone solvent and left for 15-20 minutes. Further, spot-on silica ge precoated $60 \mathrm{~F}_{254}$ aluminium sheet and then the TLC plate was developed in solvent system A, containing a mixture of toluene: dioxane: acetic acid (ratio180/60/08 v/v/v) solution used for spot running (Yılmaz et al., 2004).

\section{Antioxidant activity assay}

\section{Determination of total phenolic compounds}

The total phenolic content of methanolic extract (ME) and $70 \%$ hydroalcoholic extract (HE) of $U$. longissima was evaluated by the Folin-Ciocalteu method (Singleton and Rossi, 1965). Different doses of each sample were prepared in distilled water (DW), mixed with $1 \mathrm{~mL}$ of Folin-Ciocalteu reagent and $1 \mathrm{~mL}$ of $20 \% \mathrm{Na}_{2} \mathrm{CO}_{3}$, diluted mixture with $7 \mathrm{~mL} \mathrm{DW}$ and kept in dark for $90 \mathrm{~min}$. and absorbance was measured at $760 \mathrm{~nm}$. Results were expressed as gallic acid equivalents (GAE), which represent the amount of phenolic content in $1 \mathrm{mg}$ of sample.

\section{Determination of total flavonoid content (TFC)}

The TFC of $U$. longissima extracts was measured by the calorimetric method as described earlier (Aydin et al., 2018) with some modification. Briefly, samples were prepared at a concentration of $500 \mu \mathrm{g}$ in $6 \mathrm{~mL}$ with DW. Then $300 \mu \mathrm{L}$ of $5 \%$ $\mathrm{NaNO}_{2}$ and $300 \mu \mathrm{L}$ of Aluminium chloride $\left(10 \% \mathrm{AlCl}_{3}\right)$ were added followed by incubation of $6 \mathrm{~min}$ room temperature (RT). Then $2 \mathrm{~mL}$ of $1 \mathrm{M} \mathrm{NaOH}$ was added and the mixture was diluted with $2.5 \mathrm{~mL}$ of DW. The TFC of the extract was calculated by plotting a standard curve of rutin with five different concentration ranges $(20-100 \mu \mathrm{g})$ and expressed as quercetin equivalents $(\mathrm{mgQE} / \mathrm{g})$.

\section{DPPH (1, 1-diphenyl-2-picryl-hydrazyl) free radical Scavenging Assay}

The quantitative free radical scavenging effects of $U$. longissima extract were measured by DPPH assay, the method described by (Xu W et al., 2009) with few changes. Extract was prepared at different concentrations $(100-500 \mu \mathrm{g} / \mathrm{mL})$ and mixed with $2 \mathrm{~mL}$ of $0.1 \mathrm{mM}$ solution of DPPH in $95 \%$ solutions. The solution was shaken vigorously and incubated at room temperature for $20 \mathrm{~min}$. the percentage of radical scavenging was determined by observing the change in color from dark purple to pale yellow, which can be measured by taking absorbance at $517 \mathrm{~nm}$. Ascorbic acid was used as a positive control.

\section{Ferric Reducing Power Assay}

The reducing power of $U$. longissima extract was determined by the method (Yen et al., 2005) with slight modification. Briefly, $1 \mathrm{~mL}$ of Usnea longissima extract were prepared at each dose of $100-500 \mu \mathrm{g} / \mathrm{mL}$ and mixed with $2.5 \mathrm{~mL}$ of phosphate buffer $(0.2 \mathrm{M}, \mathrm{pH} 6.8), 2.5 \mathrm{~mL}$ of $1 \%$ potassium ferri-cyanide and incubated at $50^{\circ} \mathrm{C}$ for 20 min., $2.5 \mathrm{~mL}$ of $10 \%$ TCA was added to stop the reaction. After centrifuged to $1000 \mathrm{x} \mathrm{g}$ for $10 \mathrm{~min}, 2.5 \mathrm{~mL}$ of the upper layer was taken, mixed with $2.5 \mathrm{~mL}$ of $\mathrm{DW}$ and $0.5 \mathrm{~mL}$ of $0.1 \%$ ferric chloride $\left(\mathrm{FeCl}_{3}\right)$ The absorbance of the final mixture was measured at $700 \mathrm{~nm}$. Higher absorbance indicates greater reducing power.

\section{Hydroxyl radical scavenging activity}

Usnea longissima extract samples (100-500 $\mu \mathrm{g} / \mathrm{mL})$ in $1 \mathrm{~mL}$ DW respectively, were added to $1 \mathrm{mM} 0.1 \mathrm{~mL}$ EDTA, $0.01 \mathrm{~mL}$ of $10 \mathrm{mM} \mathrm{FeCl}_{3}, 0.1 \mathrm{~mL}$ of $10 \mathrm{mM}$ $\mathrm{H}_{2} \mathrm{O}_{2}, 0.36 \mathrm{~mL}$ of $2.8 \mathrm{mM}$ deoxyribose, $0.33 \mathrm{~mL}$ of phosphate buffer $(50 \mathrm{mM})$ and $0.1 \mathrm{~mL}$ of ascorbic acid $(1 \mathrm{mM})$. This mixture was incubated at $37^{\circ} \mathrm{C}$ for 1 hour After incubation, $1 \mathrm{~mL}$ of $10 \%$, TCA and $1 \mathrm{~mL}$ of $1 \%$ TBA were added then the mixture was boiled at $90^{\circ} \mathrm{C}$ for $30 \mathrm{~min}$. The color change was measured by taking absorbance at $532 \mathrm{~nm}$ (Pal et al., 2010).

\section{Assessment of antimicrobial activity}

The antimicrobial activity of $U$. longissima extract was determined through aga well diffusion assay against bacterial and fungal pathogens. The test microorganism was revived on nutrient agar medium overnight and the cell suspension was prepared by suspended bacteria in sterile saline water $(0.85 \%$ saline) and adjusted the inoculum density according to $0.5 \mathrm{McF}$ arland turbidity standard i.e. $1 \times 10^{5}$ to $2 \times 10^{5} \mathrm{CFU} / \mathrm{mL}$. Similarly, fungus culture was grown on PDA for 48 to $72 \mathrm{hrs}$ and fungal filaments were used to inoculate in sabouraud dextrose broth. $100 \mu \mathrm{L}$ of each suspended microorganism culture equally spread on sterile MHA and PDA Petri plates. Sterile cork borer was used to create wells of size $6 \mathrm{~mm}$ diameter. Each sample was prepared for $15 \mathrm{mg} / \mathrm{mL}$ concentration in $20 \%$ DMSO. Each well was properly labeled and supplemented with extracts sample of concentration $600 \mu \mathrm{g} / \mathrm{mL}$. For positive control, Streptomycin was used for bacterial pathogens and Ketoconazole was used for fungal pathogens, both at $10 \mu \mathrm{g} / \mathrm{mL}$ concentration. Whereas, for negative control $20 \%$ DMSO was used Bacterial Petri plates were incubated at $\pm 37^{\circ} \mathrm{C}$ for $24 \mathrm{hrs}$ and the fungal Petri plate was incubated at $\pm 25^{\circ} \mathrm{C}$ for $48 \mathrm{hrs}$. The extract's sensitivity against microorganisms was determined by measured the diameter of the zone of inhibition (ZOI, in $\mathrm{mm}$ ) formed around each well. All the antimicrobial activities were performed in triplicate.

\section{Minimum inhibitory concentration (MIC)}

It represents the minimum concentration of crude extract of lichen at which no bacterial population can survive in a particular medium. The micro-dilution technique was used to determine the MIC of lichen extract against test pathogens Lichen crude extracts serially diluted to concentration range $100-600 \mu \mathrm{g} / \mathrm{mL}$. For positive control untreated bacterial and fungal pathogens were used. The test was performed in 96 well plates, $100 \mu \mathrm{L}$ Luria broth for bacteria and Potato dextrose broth for fungus were inoculated with $20 \mu \mathrm{L}$ suspended pathogens in each well. Usnea longissima crude extract was added at different concentrations of 100-600 $\mu \mathrm{g} / \mathrm{mL}$ and incubated at $\pm 37^{\circ} \mathrm{C}$ for $24 \mathrm{hrs}$ (bacteria) and $\pm 25^{\circ} \mathrm{C}$ for $48 \mathrm{hrs}$ (fungus). $0.1 \mathrm{mM}$ Alamar Blue reagent was add in each well and incubate culture for the predetermined time in an incubator at $37^{\circ} \mathrm{C}$. After the incubation, absorbance was taken at $570 \mathrm{~nm}$ and $600 \mathrm{~nm}$ wavelengths. Alamar blue is nontoxic and enters into the cell then the blue color turns pink due to the reduction of resazurin dye. Viable cells continuously reduce resazurin that gives pink color. 


\section{Antiquorum sensing and antibiofilm activity}

\section{Antiquorum sensing activity}

Antiquorum sensing activity was determined by the standard overlay method. A quorum-sensing test was performed on the biomonitor strain of C. violaceum bacteria produce quorum sensing regulated violet color pigment called violacein (Truchado et al., 2009). First, the inoculum was prepared in normal saline and maintaining a cell density of $0.5 \mathrm{OD}$ at $600 \mathrm{~nm}$. LB agar was prepared with $0.3 \%$ agar and inoculum was added after cooling to $40^{\circ} \mathrm{C}$, before solidifying. This $3 \%$ LB agar was used to overlay on previously prepared LB agar plates to form a layer on it. When agar was solidifying, the disc was placed and different concentrations of extract solution $\left(100,200\right.$ and $\left.300 \mu \mathrm{g} \mathrm{disk}^{-1}\right)$ were dropped on the disc. $50 \%$ of DMSO was used for negative control. Plates were incubated at $30^{\circ} \mathrm{C}$ overnight.

\section{Quantification of violacein production}

Inhibitory activity of $U$. longissima extract against violacein production in $C$ violaceum was performed according to the method (Singh et al., 2009). A culture of $C$. violaceum was grown in Luria broth in test tubes containing $5 \mathrm{~mL}$ media and treated with extract at three different concentration ranges from 100-300 $\mu \mathrm{g} / \mathrm{mL}$. Bacterial cells were incubated for 24 hours at $30^{\circ} \mathrm{C}$ and lysed by adding $10 \%$ SDS. Violacein was extracted by adding $\mathrm{n}$-butanol and vortex it properly and centrifuge at $10,000 \mathrm{rpm}$ for $10 \mathrm{~min}$. The upper butanol layer was isolated and absorbance was taken at $585 \mathrm{~nm}$.

\section{Biofilm Inhibition assay}

Effect of $U$. longissima extract on biofilm inhibition was tested against $B$. cereus, C. albican, E. coli, P. aeruginosa, S. aureus, according to the previously described method (Singh et al., 2012). An overnight grown microbial culture was used to inoculate $(1 \% \mathrm{v} / \mathrm{v})$ media in the petri dish $(55 \times 12)$ and sterile glass cover-slips are also placed in a petri dish. These cultures were treated with methanolic extract in three different concentrations $100-300 \mu \mathrm{g} / \mathrm{mL}$, for bacteria strains and $50-150 \mu \mathrm{g} / \mathrm{mL}$, for fungal strain, followed by incubation of 24 hours at $37 \pm 2^{\circ} \mathrm{C}$. After incubation media were discarded carefully so that formed biofilm was not getting disturbed and washed with phosphate buffer (PBS). The biofilms that were got adhere to a glass coverslip were stained with $10 \%$ crystal violet dye and washed again with PBS. Inhibition in biofilm formation was examined under a microscope (Leica DM 2500) in a bright field.

\section{RESULTS}

\section{Total phenol and Flavonoid content}
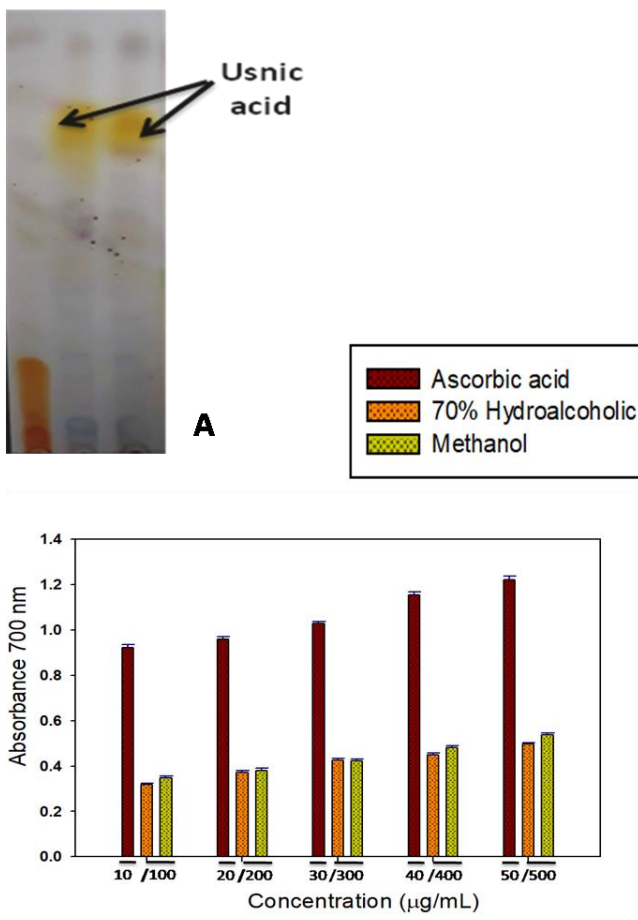

C
Usnea longissima is rich in phenolic compounds, the total phenolic content of $U$. longissima in $\mathrm{HE}$ and ME was found to be $24.04 \pm 0.05 \mu \mathrm{g}$ and $20.73 \pm 0.01 \mu \mathrm{g}$ gallic acid equivalents, phenols content in $1 \mathrm{mg}$ of $U$. longissima extract However, flavonoid content was found in a negligible amount in both extracts of U. longissima.

\section{Major chemical compounds}

Two compounds identified in the TLC result that is- usnic acid and very low barbatic acid (Figure 1A). The characterization of the compounds was based on the calculated $R_{f}$ value.

\section{Determination of antioxidant activity}

The DPPH free radical scavenging activity of extracts was increased in a concentration-dependent manner (Figure 1B). But, the overall scavenging property of $U$. longissima is low (5-10\%) in $\mathrm{HE}$ and (10-20\%) in ME at 100-500 $\mu \mathrm{g} / \mathrm{mL}$, as compared to standard ascorbic acid with $(50-94 \%)$ radical scavenging activity at $10-50 \mu \mathrm{g} / \mathrm{mL}$ concentration.

Table $1 \mathrm{IC}_{50}$ value of Usnea longissima extracts

\begin{tabular}{lccc}
\hline & \multicolumn{3}{c}{ IC $_{\mathbf{5 0}}$ concentration $(\boldsymbol{\mu g} / \mathbf{m L})$} \\
\hline Antioxidant assays & $\begin{array}{c}70 \% \text { hydroalcoholic } \\
\text { extract }\end{array}$ & $\begin{array}{c}\text { Methanolic } \\
\text { extract }\end{array}$ & $\begin{array}{c}\text { Ascorbic } \\
\text { acid }\end{array}$ \\
$\begin{array}{l}\text { DPPH } \\
\text { Ferric reducing }\end{array}$ & $321 \pm 22$ & $334 \pm 18$ & $10.7 \pm 0.35$ \\
$\begin{array}{l}\text { power } \\
\text { Hydroxyl radical } \\
\text { scavenging }\end{array}$ & $133 \pm 15$ & $141 \pm 12$ & $4.2 \pm 0.25$ \\
\hline
\end{tabular}

* Data represented as mean $\pm \mathrm{SD}$ of three independent readings.

In reducing power assay, results demonstrate a dose-dependent activity in both extracts (Figure 1C). The ME showed higher activity than $\mathrm{HE}$ at the concentration range $(100-500 \mu \mathrm{g} / \mathrm{mL})$. Reducing power ability of $U$. longissima extracts is half potential when compared to standard ascorbic acid at 10-50 $\mu \mathrm{g} / \mathrm{mL}$ concentration. Hydroxyl radical scavenging activity of $U$. longissima extract showed concentration-dependent increased in scavenging activity (Figure1D). Around $50 \%$ of radical scavenging was observed in both extracts at $500 \mu \mathrm{g} / \mathrm{mL}$ concentration. While ascorbic acid showed $80-85 \%$ Hydroxyl radical scavenging at a concentration of $50 \mu \mathrm{g} / \mathrm{mL}$. These antioxidant results demonstrated that $U$. longissima metabolite expresses potential reducing power and hydroxyl radical scavenging properties. Results of the $\mathrm{IC}_{50}$ value of $U$. longissima extract of the different assays are represented in (Table 1).

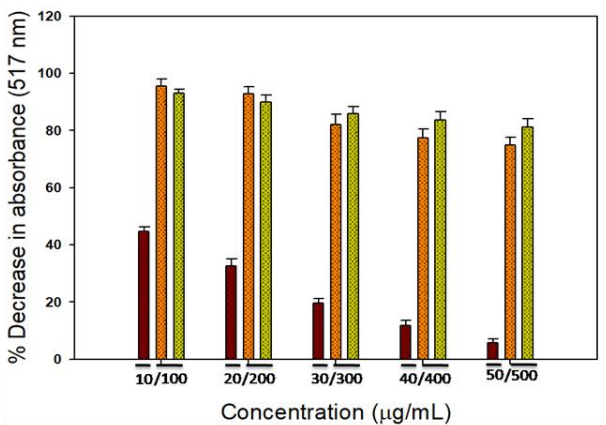

B

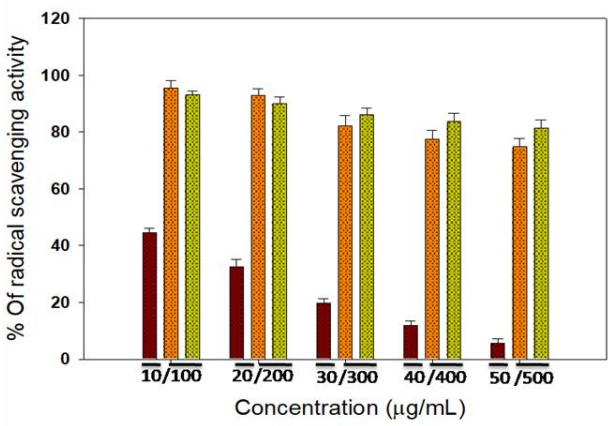

D

Figure 1 TLC plate image (yellow spots represent Usnic acid) (A) DPPH assay (B) Reducing power assay (C) Hydroxyl radical scavenging assay (D) of $U$. longissima extracts in different solvents. Results are represented in terms of change in absorbance and radical scavenging Percentage. The test was performed in triplicates and all values were considered as mean $\pm \mathrm{SD}$ of three independent experiments with $\mathrm{P}>0.05$. 


\section{Antimicrobial activity}

Antimicrobial assay results revealed that lichen crude extract showed a varied range of antimicrobial activity against the tested microorganism (Table 2). ME showed broad-spectrum antimicrobial activity against all pathogens (except $A$. niger). Among them, the most significant activity was reported against $C$. albicans $(30 \pm 0.3 \mathrm{~mm})$ and $A$. tumifaciens $(24 \pm 0.2 \mathrm{~mm})$.

The MIC of all lichen extracts was tested against respective human and plant pathogenic bacteria and fungus using Alamar blue assay in 96 well microtiter plates (Table 2). Methanolic and acetone extracts showed significan antimicrobial activity against $C$. albicans with MIC $200 \mu \mathrm{g} / \mathrm{mL}$ and $400 \mu \mathrm{g} / \mathrm{mL}$ respectively. The MIC of $A$. tumifaciens was $400 \mu \mathrm{g} / \mathrm{mL}$ for acetone extract $300 \mu \mathrm{g} / \mathrm{mL}$ in methanol and $70 \%$ hydroalcoholic extract. $P$. aeruginosa showed complete inhibition at $600 \mu \mathrm{g} / \mathrm{mL}$ in all extracts of $U$. longissima. Similarly, the MIC range for $S$. mutans was $400-500 \mu \mathrm{g} / \mathrm{mL}$ for different extracts.

Table 2 Zone of inhibition (ZOI) and MIC value of Usnea longissima in a crude extract of acetone, methanol, and 70\% hydroalcoholic

\begin{tabular}{|c|c|c|c|c|c|c|c|c|}
\hline Microorganisms & Acetone & $\begin{array}{c}\text { MIC } \\
\mu \mathrm{g} / \mathrm{mL}\end{array}$ & Methanol & $\begin{array}{c}\text { MIC } \\
\mu \mathrm{g} / \mathrm{mL}\end{array}$ & 70\% Hydroalchoholic & $\begin{array}{c}\text { MIC } \\
\mu \mathrm{g} / \mathrm{mL}\end{array}$ & +ve control & -ve control \\
\hline \multicolumn{9}{|l|}{ Bacteria } \\
\hline $\begin{array}{l}\text { Agrobactreium } \\
\text { tumefaciens }\end{array}$ & $22 \pm 0.7$ & 400 & $24 \pm 0.2$ & 300 & $20 \pm 0.5$ & 300 & $25 \pm 0.5$ & 00 \\
\hline Escherichia coli & $10 \pm 0.3$ & 500 & $11 \pm 0.2$ & 400 & $07 \pm 0.3$ & 600 & $23 \pm 0.2$ & 00 \\
\hline $\begin{array}{l}\text { Klebsiella } \\
\text { pneumoniae }\end{array}$ & $13 \pm 0.2$ & 600 & $15 \pm 0.3$ & 500 & $11 \pm 0.2$ & 600 & $26 \pm 0.2$ & 00 \\
\hline $\begin{array}{l}\text { Pseudomonas } \\
\text { aeruginosa }\end{array}$ & $15 \pm 0.1$ & 600 & $18 \pm 0.2$ & 600 & $10 \pm 0.2$ & 600 & $28 \pm 00$ & 00 \\
\hline $\begin{array}{l}\text { Stephyllococcus } \\
\text { aureus }\end{array}$ & $20 \pm 0.2$ & 500 & $23 \pm 0.2$ & 500 & $20 \pm 0.3$ & 500 & $28 \pm 00$ & 00 \\
\hline $\begin{array}{l}\text { Streptococcus } \\
\text { mutans }\end{array}$ & $19 \pm 0.2$ & 500 & $22 \pm 0.2$ & 400 & $16 \pm 0.5$ & 500 & $23 \pm 00$ & 00 \\
\hline \multicolumn{9}{|l|}{ Fungus } \\
\hline $\begin{array}{l}\text { Candida } \\
\text { albicans }\end{array}$ & $25 \pm 0.2$ & 400 & $30 \pm 0.3$ & 200 & $22 \pm 0.2$ & 400 & $38 \pm 0.2$ & 00 \\
\hline Aspergillus niger & $12 \pm 0.2$ & 500 & $10 \pm 0.2$ & 600 & $09 \pm 0.2$ & 600 & $25 \pm 0.2$ & 00 \\
\hline
\end{tabular}

* The average value of three calculations is presented as mean \pm S.D. (standard deviation) Positive control: Streptomycin, ketoconazole $10 \mu \mathrm{g} / \mathrm{mL} ;$ Negative control: $20 \%$ DMSO Included diameter of well $6 \mathrm{~mm}$.

\section{Antiquorum sensing activity}

Antiqurom sensing results were determined by observing the halo zone (withou violacein pigment) around the disc (Figure 2B). The overlay disc diffusion assay on $C$. violaceum showed a clear halo zone around the disc treated with samples. All the extracts were showing antiquorum sensing activity against $C$. violaceum as the bacterial cells were grown without the production of violacein pigment Most significan activities were reported in $\mathrm{ME}$ and $\mathrm{HE}$, while acetone extract showed moderate activity and no activities were reported in the negative control.

The effect of $U$. longissima extracts in the production of violacein pigmen in $C$. violaceum (Figure 2A). Significant inhibition of violacein production by $U$. longissima in a dose-dependent manner was seen (Figure 2C). The most significant inhibition was observed in $\operatorname{ME}(81 \%)$, HE $(75 \%)$ at $300 \mu \mathrm{g} / \mathrm{mL}$. whereas more than $50 \%$ inhibition was observed in each extract at $200 \mu \mathrm{g} / \mathrm{mL}$ concentration.

\section{Biofilm Inhibition}

Inhibition of biofilm formation in B. cereus, C. albican, E. coli, P. aeruginosa, $S$ aureus, by $U$. longissima extract was performed by crystal violet staining method. Biofilm inhibition results were observed under a microscope (Lieca DM 2500) and represented in the form of images (Figure 2D) further quantitative data revealed that $U$. longissima extract causes destruction of biofilm in a concentration-dependent manner. $50 \%$ biofilm inhibition was observed in bacterial pathogenic strains at $200 \mu \mathrm{g} / \mathrm{mL}$ methanolic extract while at $50 \mu \mathrm{g} / \mathrm{mL}$ for C. albicans.

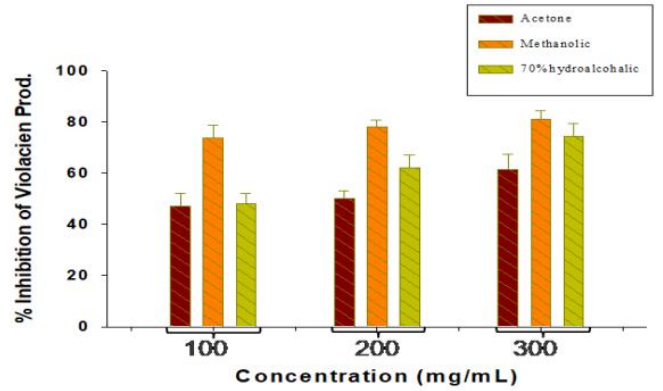

A

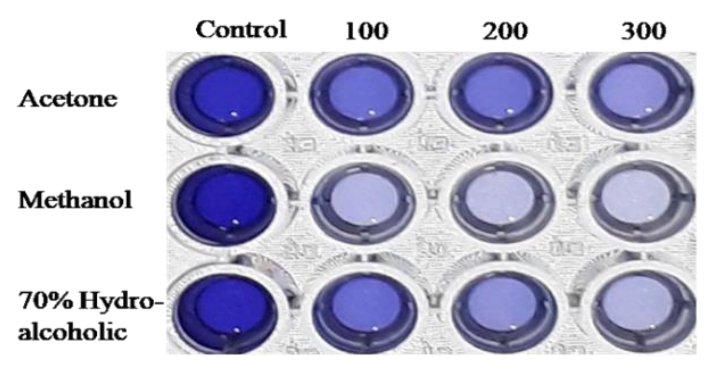

C
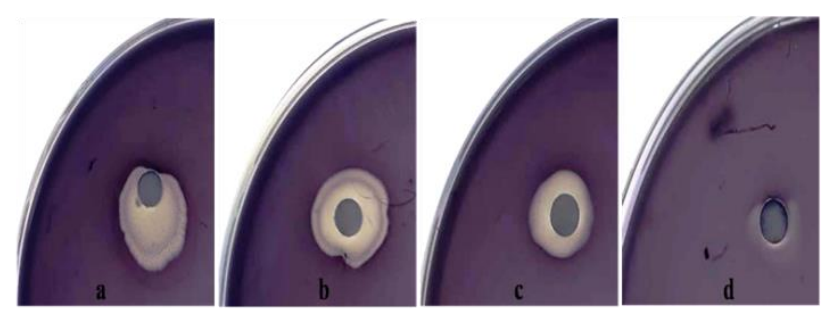

B

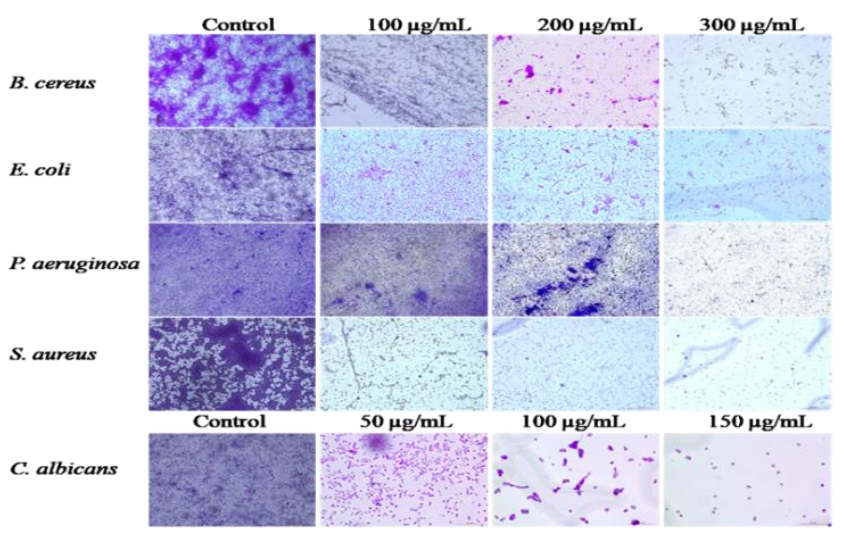

D

Figure 2 Quantification of violacein production, results are shown as percentage inhibition in violacein production. Data represented in mean value \pm SD (A) Antiquorum sensing activity (a) Methanolic (b) $70 \%$ hydroalcoholic (c) Acetone extract (d) $50 \%$ DMSO. The halo zone around the disc represents inhibition of quorum sensing in biomonitor strain C. violaceum (B). Qualitative Representation of inhibition in violacein production w.r.t. control in all extracts (C). Show inhibition of biofilm Formation in B.cereus, E. coli, P.aeruginosa, S. aureus, C. albicans. Complete eradication of biofilm was observed at $300 \mu \mathrm{g} / \mathrm{mL}$ and $150 \mu \mathrm{g} / \mathrm{mL}($ Candida albicans) concentration w.r.t. to the non-treated control (D). 


\section{DISCUSSION}

In the light of the present study, we extracted $U$. longissima secondary metabolites in different solvents to extract the maximum possible compounds of different polarities and verify antimicrobial and antiquorum sensing activity of different extracts. Results of experiments validate the traditional uses of $U$. longissima by showing a varied range of activity with different extracts in concentrations range between $(100-600 \mu \mathrm{g} / \mathrm{mL})$. The most prominen antimicrobial activity was reported in ME against $C$. albicans at MIC value $200 \mu \mathrm{g} / \mathrm{mL}$, these results are corresponding to earlier reports where the significant anticandidal activity of $U$. longissima in the ethanolic extract was reported (Rauf et al., 2011; Thippeswamy et al., 2011). While in another study (Sudarwanti et al., 2018) identified acetone extract of $U$. longissima promising against $C$. albicans. However, few studies have been done in detail for the anticandidal activity of $U$. longissima. (Pavithra et al., 2013) reported anticandidal activity in Usnea pictoides chloroform, ethyl acetate and methanolic extract at $2 \mathrm{mg} / \mathrm{mL}$ concentration. Their study suggested usnic acid the major bioactive compound responsible for antimicrobial activity. Usnic acid isolated from Cladonia foliaced has shown inhibition of a panel of bacteria and fungi that included $S$. aureus and C. albicans (Yilmaz et al., 2004). We reported moderate to non-significan activity against $E$. coli, previous studies also reported $U$. longissima extracts noneffective against $E$. coli and significant activity of HE, ME and ethyl acetate extracts against $K$. pneumoniae in (Rauf et al., 2011; Kamal et al., 2015; Kumar et al., 2017). P. aeruginosa is a Gram-negative opportunistic pathogen capable of infecting humans with compromised natural defenses and causing severe pulmonary disease. This bacterium has the remarkable property of biofilm formation which allows them to become resistant to many drugs (Alhazmi, 2015). We found significant activity against $P$. aeruginosa in $\mathrm{ME}$ as compared to $\mathrm{HE}$ and acetone extract. The antibacterial potential of methanolic and hydroalcoholic extracts against $P$. aeruginosa was also reported in separate studies. (Rauf et al., 2011; Srivastava et al., 2013; Kamal et al., 2015; Kumar et al., 2017). All the extracts in the present study showed strong antibacterial activity against $S$. aureus and $S$. mutans corresponds to other studies where they reported moderate activity in $50 \%$ alcoholic extract (Rauf et al., 2011; Srivastava et al., 2013) and in acetone extract $(10.65 \pm 0.4 \mathrm{~mm})$ which was found to be half potential activity as compared to present results (Sudarwanti et al. 2018). When Usnic acid, a major compound present in Usnea species, tested against $P$. aeruginosa, $S$. aureus and $E$. coli gives significant antimicrobial activity (Ananthi et al., 2016). However, all the results of the present study are not as eminent when compared to standard streptomycin.

Antioxidant activity of $U$. longissima extract suggested significant radical scavenging activity in reducing power and hydroxyl radical scavenging assay except for DPPH. Despite the presence of phenolic compounds in Usnea, it extract was showing low DPPH activity. Previous studies reported that the $U$. longissima compound was not scavenged DPPH significantly (Kumar and Muller, 1999; Atalay et al., 2011). However, Verma et al. (2017) reported significant DPPH radical scavenging activity in the ethanolic extract, higher than standard ascorbic acid. Varying results of antimicrobial and antioxidant scavenging activity may be due to a geographical difference in the area of collected samples (Deduke $\boldsymbol{e t}$ al., 2012) or enantiomer character of usnic acid Usnic acid has two enantiomer structure and each enantiomer have different biological activity (Singh et al., 2012).

We evaluated the antiquorum sensing potential of $U$. longissima extracts in bacterial strain $C$. violaceum. Results showed inhibition in quorum sensing at al ranges of treatment doses. A similar effect was reported in the biofilm inhibition experiment against B. cereus, C. albican, E. coli, P. aeruginosa, S. aureus Previously, it was suggested that usnic acid, a major component of $U$. longissima causes interference with signaling pathways in pathogens (Maciag-Dorszynska et al., 2014; Milot et al., 2017; Nithyanand et al., 2015; Ozyigitoglu and Acikgoz, 2017) and could be a possible mechanism of antibiofilm and antiquorum activity of $U$. longissima.

\section{CONCLUSIONS}

It is clear from the present study that the usnic acid of $U$. longissima is acting as a potential antimicrobial agent against human as well as plant pathogens. Among different fractions, the methanolic extract is more potential, specifically against C. albicans and plant pathogen A. tumefaciens (Gram-negative bacteria). Its extract contains a unique phenolics compound that shows significant antioxidan activity. Moreover, $U$. longissima also acts as a potential antiquorum sensing agent and could be an alternative source of antibacterial agents. Owing to the unique metabolites and potent antimicrobial, antiquorum and antioxidant activity $U$. longissima metabolites could be significantly used further for the control of urinary tract infection or as food-borne and immune-suppressed diseases thus provide a huge reservoir for the production of antibiotics therapy that cures humans and plants infectious and antibiotic-resistant diseases in the future.

Abbreviation ME=Methanolic extract, $\mathrm{HE}=70 \%$ hydroalcoholic extract, $\mathrm{DW}=$ Distilled water.
Acknowledgments: Authors are thankful to The Director, CSIR- Nationa Botanical Research Institute, Lucknow and H.O.D. of Microbiology Department, Babasaheb Bhimrao Ambedkar Central University, Lucknow for providing laboratory facilities and guidance.

Conflict of interest: There is no actual or potential conflict of interest.

\section{REFERENCES}

Alahmadi, A. A. (2017). Usnic acid biological activity: history, evaluation and

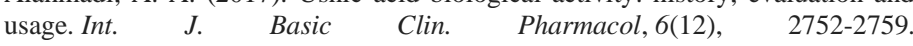
http://dx.doi.org/10.18203/2319-2003.ijbcp20175072

Alhazmi, A. (2015). Pseudomonas aeruginosa pathogenesis and pathogenic mechanisms. International Journal of Biology, 7(2), 44.44 https://doi.org/10.5539/ijb.v7n2p44

Atalay, F., Halici, M. B., Mavi, A., Cakir, A., Odabasoglu, F., Kazaz, C., \& Kufrevioglu, O. I. (2011). Antioxidant phenolics from Lobaria pulmonaria (L.) Hoffm. and Usnea longissima Ach. lichen species. Turkish Journal of chemistry, 35(4), 647-661.

Al-Wrafy, F., Brzozowska, E., Górska, S., \& Gamian, A. (2017). Pathogenic factors of Pseudomonas aeruginosa-the role of biofilm in pathogenicity and as a target for phage therapy. Advances in Hygiene \& Experimental Medicine/Postepy Higieny $i$ Medycyny Doswiadczalnej, 71 https://doi.org/10.5604/01.3001.0010.3792

Aydin, S., Kinalioğlu, K., \& Sökmen, B. B. (2018). Antioxidant, anti-urease and anti-elastase activities of Usnea longissima Ach. Bangladesh Journal of Botany, 47(3), 429-435. https://doi.org/10.3329/bjb.v47i3.38680

Ananthi, R., Tinabaye, A., Ganesan, T., Selvaraj, G., Arulmozhi, S., Senthil, Kumar, S. (2016). Antimicrobial and anti-inflammatory activity of usnic acid and its acetyl derivative usnic acid diacetate. Journal of Scientific and Engineering Research, 4, 356-66

Bao, H. Y., \& Bau, T. (2013). Advance in studies on chemical constituents and pharmacological activity of lichens in Usnea genus. Zhongguo Zhong yao za zhi Zhongguo zhongyao zazhi China journal of Chinese materia medica, 38(4), 539545 .

Behera, B. C., Mahadik, N., \& Morey, M. (2012). Antioxidative and cardiovascular-protective activities of metabolite usnic acid and psoromic acid produced by lichen species Usnea complanata under submerged fermentation. Pharmaceutical Biology, 50(8), $\quad 968-979$. https://doi.org/10.3109/13880209.2012.654396

Blumenthal, M., Goldberg, A., \& Brinckmann, J. (2000). Herbal Medicine. Expanded Commission E monographs. Integrative Medicine Communications. https://doi.org/10.7326/0003-4819-133-6-200009190-00031

Bjerke, J. W., Joly, D., Nilsen, L., \& Brossard, T. (2004). Spatial trends in usnic acid concentrations of the lichen Flavocetraria nivalis along local climatic gradients in the Arctic (Kongsfjorden, Svalbard). Polar Biology, 27(7), 409-417 https://doi.org/10.1007/s00300-004-0590-8

Bendz, G., Bohman, G., \& Santesso. J. (1967). chemical studies on lichens. 5 Separation and identification of antipodes of usnic acid by thin layer chromatography. Acta Chemica Scandinavica, 21(5), 1376.

Choudhary, M. I., \& Jalil, S. (2005). Bioactive phenolic compounds from a medicinal lichen, Usnea longissima. Phytochemistry, 66(19), 2346-2350. https://doi.org/10.1016/j.phytochem.2005.06.023

Correché, E. R., Enriz, R. D., Piovano, M., Garbarino, J., \& Gómez-Lechón, M J. (2004). Cytotoxic and apoptotic effects on hepatocytes of secondary metabolites obtained from lichens. Alternatives to Laboratory Animals, 32(6) 605-615. https://doi.org/10.1177/026119290403200611

Dandapat, M., \& Paul, S. (2019). Secondary metabolites from lichen Usnea longissima and its pharmacological relevance. Pharmacognosy Research, 11(2), 103. https://doi.org/10.4103/pr.pr_111_18

Deduke, C., Timsina, B., \& Piercey-Normore, M. D. (2012). Effect of environmental change on secondary metabolite production in lichen-forming fungi. International perspectives on global environmental change. InTech, 197 230. https://doi.org/10.5772/26954

IFlemming, H. C., \& Wuertz, S. (2019). Bacteria and archaea on Earth and their abundance in biofilms. Nature Reviews Microbiology, 17(4), 247-260. https://doi.org/10.1038/s41579-019-0158-9

Girard, G., \& Bloemberg, G. V. (2008). Central role of quorum sensing in regulating the production of pathogenicity factors in Pseudomonas aeruginosa. https://doi.org/10.2217/17460913.3.1.97

Gökalsın, B., \& Sesal, N. C. (2016). Lichen secondary metabolite evernic acid as potential quorum sensing inhibitor against Pseudomonas aeruginosa. World Journal of Microbiology and Biotechnology, 32(9), https://doi.org/10.1007/s11274-016-2105-5

Guo, S. Y., Liu, W. X., Han, L. F., \& Chen, J. Z. (2017). Antifungal activity of lichen extracts and usnic acid for controlling the saprolegniasis. International Journal of Environmental \& Agriculture Research, 3, 43-47. https://doi.org/10.25125/agriculture-journal-ijoear-apr-2017-35 
Kamal, S., Manish, S., Savita, J., Jasumati. (2015), Assessment of Antibacteria Activity of Usnea Species of ShimLa Hills. Int J Curr Microbiol App Sci, 4, 41325.

Nishanth, K. S., Sreerag, R. S., Deepa, I., Mohandas, C., \& Nambisan, B. (2015) Protocetraric acid: an excellent broad spectrum compound from the lichen Usnea albopunctata against medically important microbes. Natural product research, 29(6), 574-577. https://doi.org/10.1080/14786419.2014.953500

Kosanić, M., Ranković, B., \& Vukojević, J. (2011). Antioxidant properties of some lichen species. Journal of food science and technology, 48(5), 584-590. https://doi.org/10.1007/s13197-010-0174-2

Kumar, V., Tripathi, M., Mathela, C. S., \& Joshi, Y. (2017). In vitro antibacteria activity of Himalayan lichenized Fungi. Journal of Pharmacognosy and Natural Products, 3(128), 2472-0992. https://doi.org/10.4172/2472-0992.1000128

Kumar KC, S., \& Müller, K. (1999). Lichen metabolites. 1. Inhibitory action against leukotriene B4 biosynthesis by a non-redox mechanism. Journal of natural products, 62(6), 817-820. http://dx.doi.org/10.1021/np9803777

Maciag-Dorszyńska, M., Wegrzyn, G., \& Guzow-Krzemińska, B. (2014). Antibacterial activity of lichen secondary metabolite usnic acid is primarily caused by inhibition of RNA and DNA synthesis. FEMS microbiology letters, 353(1), 57-62. https://doi.org/10.1111/1574-6968.12409

Madamombe, I. T., \& Afolayan, A. J. (2003). Evaluation of antimicrobial activity of extracts from South African Usnea barbata. Pharmaceutical Biology, 41(3), 199-202. https://doi.org/10.1076/phbi.41.3.199.15089

Millot, M., Girardot, M., Dutreix, L., Mambu, L., \& Imbert, C. (2017) Antifungal and anti-biofilm activities of acetone lichen extracts against Candida albicans. Molecules, 22(4), 651. https://doi.org/10.3390/molecules22040651

Molnár, K., \& Farkas, E. (2010). Current results on biological activities of lichen secondary metabolites: a review. Zeitschrift für Naturforschung C, 65(3-4), 157 173. https://doi.org/10.1515/znc-2010-3-401

Nithyanand, P., Shafreen, R. M. B., Muthamil, S., \& Pandian, S. K. (2015). Usnic acid, a lichen secondary metabolite inhibits Group A Streptococcus biofilms. Antonie van Leeuwenhoek, 107(1), 263-272. https://doi.org/10.1007/s10482-014-0324-z

Ozyigitoglu, G., \& Acikgoz, B. (2017). Comparison of antibacterial and antibiofilm activity properties of Hypogymnia tubulosa (Schaer.) Hav. lichen extracts from different locations in Turkey. https://doi.org/10.5943/mycosphere/8/8/2

Pal, J., Ganguly, S., Tahsin, K., S., Acharya, K,. (2010). In vitro free radical scavenging activity of wild edible mushroom, Pleurotus squarrosulus (Mont.) Singer. Indian J Exp Biol, 47, 1210-18.

Paliya, B. S., Bajpai, R., Jadaun, V., Kumar, J., Kumar, S., Upreti, D. K., \& Singh, B. N. (2016). The genus Usnea: a potent phytomedicine with multifarious ethnobotany, phytochemistry and pharmacology. RSC advances, 6(26), 21672 21696. https://doi.org/10.1039/c5ra24205c

Pavithra, G. M., Vinayaka, K. S., Rakesh, K. N., Junaid, S., Dileep, N., TR, P. K., \& Naik, A. S. (2013). Antimicrobial and antioxidant activities of a macrolichen Usnea pictoides G. Awasthi (Parmeliaceae). Journal of Applied Pharmaceutical Science, 3(8), 154. DOI: 10.7324/JAPS.2013.3827

Rauf, A., Latif, A., Rehman, S., \& Afaq, S. H. (2011). In-vitro antibacteria screening of extracts of Usnea longissima lichen. Int J Appl Biol Pharm Technol, 2, 14-18

Shah, S., Gaikwad, S., Nagar, S., Kulshrestha, S., Vaidya, V., Nawani, N., \& Pawar, S. (2019). Biofilm inhibition and anti-quorum sensing activity of phytosynthesized silver nanoparticles against the nosocomial pathogen Pseudomonas aeruginosa. Biofouling, 35(1), 34-49. https://doi.org/10.1080/08927014.2018.1563686

Shahi, S. K., Shukla, A. C., Dikshit, A., \& Uperti, D. K. (2001). Broad spectrum antifungal properties of the lichen Heterodermia leucomela. The Lichenologist, 33(2), 177-179. https://doi.org/10.1006/lich.2000.0303

Shivanna, R. \& Garampalli, R. H. (2014). Efficacy of lichen extracts as biocontrol agents against Fusarium oxysporum F. sp. capsici. Adv. Appl. Sci. Res, 5(5), 273-277.

Sifri, C. D. (2008). Quorum sensing: bacteria talk sense. Clinical infectious diseases, 47(8), 1070-1076. https://doi.org/10.1086/592072

Singh, B. N., Singh, B. R., Singh, R. L., Prakash, D., Dhakarey, R., Upadhyay, G., \& Singh, H. B. (2009). Oxidative DNA damage protective activity, antioxidant and anti-quorum sensing potentials of Moringa oleifera. Food and Chemical Toxicology, 47(6), 1109-1116. https://doi.org/10.1016/j.fct.2009.01.034

Singh, B. N., Singh, H. B., Singh, A., Singh, B. R., Mishra, A., \& Nautiyal, C. S. (2012). Lagerstroemia speciosa fruit extract modulates quorum sensingcontrolled virulence factor production and biofilm formation in Pseudomonas aeruginosa. Microbiology, 158(2)

529-538.

https://doi.org/10.1099/mic.0.052985-0

Singleton, V. L., \& Rossi, J. A. (1965). Colorimetry of total phenolics with phosphomolybdic-phosphotungstic acid reagents. American journal of Enology and Viticulture, 16(3), 144-158.

Solano, C., Echeverz, M., \& Lasa, I. (2014). Biofilm dispersion and quorum sensing. Current opinion in microbiology, 18, 96-104 https://doi.org/10.1016/jmib.2014.02.008
Srivastava, P., Logesh, A. R., Upreti, D. K., Dhole, T. N., \& Srivastava, A. (2013). In-vitro evaluation of some Indian lichens against human pathogenic bacteria. Mycosphere, 4(4), 734-743. https://doi.org/10.5943/mycosphere/4/4/10 Sudarwanti, C., S., Imran, I., Yanti, N., A., Musdalifah, A., Nurdin, M. et al. (2018). Antimicrobial activity of acetone extract and usnic acid constituent of lichen Usnea longissima Ach. International Research Journal of Pharmacy, 9 89-98.

Thippeswamy, B., Naveenkumar, K. J., Bodharthi, J. G., \& Shivaprasad, S. R. (2011). Antimicrobial activity of ethanolic extract of Usnea longissima. Journal of Experimental Sciences.

Truchado, P., López-Gálvez, F., Gil, M. I., Tomás-Barberán, F. A., \& Allende, A (2009). Quorum sensing inhibitory and antimicrobial activities of honeys and the relationship with individual phenolics. Food Chemistry, 115(4), 1337-1344. https://doi.org/10.1016/j.foodchem.2009.01.065

Ullah, M., Uddin, Z., Song, Y. H., Li, Z. P., Kim, J. Y., Ban, Y. J., \& Park, K. H (2019). Bacterial neuraminidase inhibition by phenolic compounds from Usnea longissima. South African journal of botany, 120, 326-330. https://doi.org/10.1016/j.sajb.2018.10.020

Verma, N., Behera, B. C., \& Makhija, U. (2008). Antioxidant and hepatoprotective activity of a lichen Usnea ghattensis in vitro. Applied biochemistry and biotechnology, 151(2-3), 167-181. https://doi.org/10.1007/s12010-008-8164-9

Verma, P., Paswan, S. K., Nath, V., Gupta, R. K., Verma, S., Srivastava, S., \& Rao, C. V. (2017). Hematological, antioxidant and protective performance of Usnea longissima on chemical induced hepatotoxicity in experimental animals. $J$. Coast. Life Med, 5(5), 224-232. https://doi.org/10.12980/jclm.5.2017J6-250

Xu, W., Zhang, F., Luo, Y., Ma, L., Kou, X., \& Huang, K. (2009). Antioxidant activity of a water-soluble polysaccharide purified from Pteridium aquilinum. Carbohydrate research, 344(2),

217-222. https://doi.org/10.1016/j.carres.2008.10.021

Yen, W. J., Chang, L. W., \& Duh, P. D. (2005). Antioxidant activity of peanut seed testa and its antioxidative component, ethyl protocatechuate. LWT-Food Science $\quad$ and 193-200. https://doi.org/10.1016/j.1wt.2004.06.004

Yılmaz, M., Türk, A. Ö., Tay, T., \& Kivanç, M. (2004). The Antimicrobial Activity of Extracts of the Lichen Cladonia foliacea and Its (-)-Usnic Acid Atranorin, and Fumarprotocetraric Acid Constituents. Zeitschrift für Naturforschung C, 59(3-4), 249-254. https://doi.org/10.1515/znc-2004-3-423 Yu, X., Guo, Q., Su, G., Yang, A., Hu, Z., Qu, C., \& Chai, X. (2016). Usnic acid derivatives with cytotoxic and antifungal activities from the lichen Usnea longissima. Journal of natural products, 79(5), 1373 1380. https://doi.org/10.1021/acs.jnatprod.6b00109 